\title{
Nicaragua: Banane... mit dem kleinen Unterschied
}

Nicaragua : la banane... avec la petite différence

\section{Ueli Tecklenburg}

\section{CpenEdition}

\section{Journals}

Édition électronique

URL : http://journals.openedition.org/sjep/1082

DOI : 10.4000/sjep.1082

ISSN : 1663-9677

\section{Éditeur}

Institut de hautes études internationales et du développement

\section{Édition imprimée}

Date de publication : 1 janvier 1986

Pagination : 183-189

ISSN : 1660-5926

\section{Référence électronique}

Ueli Tecklenburg, « Nicaragua: Banane... mit dem kleinen Unterschied», Schweizerisches Jahrbuch für Entwicklungspolitik [En ligne], 6| 1986, mis en ligne le 09 mars 2013, consulté le 08 septembre 2020 URL : http://journals.openedition.org/sjep/1082 ; DOI : https://doi.org/10.4000/sjep.1082

Ce document a été généré automatiquement le 8 septembre 2020

(c) The Graduate Institute 


\section{Nicaragua: Banane... mit dem kleinen Unterschied}

Nicaragua : la banane... avec la petite différence

Ueli Tecklenburg

NOTE DE L'ÉDITEUR

Volltext auf Französisch in Annuaire suisse de politique de développement: „Nicaragua : la banane... avec la petite différence", http://aspd.revues.org/1235. 